\title{
On the formaldehyde release of wood particles
}

\author{
E. Roffael $\cdot$ C. Behn $\cdot$ B. Dix
}

Received: 23 March 2012/Published online: 20 June 2012

(C) The Author(s) 2012. This article is published with open access at Springerlink.com

\begin{abstract}
The emission of formaldehyde from softwood particles, as measured by the flask method (EN 717-3), depends highly on the particle size. Therefore, no definite value for the formaldehyde release from wood can be given.
\end{abstract}

\section{Die Formaldehydabgabe von Holzspänen}

Zusammenfassung Die Formaldehydemission von Nadelholzspänen verschiedener Größe wurde nach der Flaschenmethode (EN 717-3) bestimmt. Es zeigte sich, dass die Formaldehydabgabe sehr stark von der Partikelgröße abhängt. Demzufolge kann für die Holzspäne kein definierter Formaldehydabgabewert angegeben werden.

\section{Introduction}

Since recently increasing attention has been paid to the issue of formaldehyde emission from wood based panels. The ultimate goal is to reduce the formaldehyde release of wood composites to the level of wood itself (Boehme 2000; Hasch and Grunwald 2006). In this context the question arose whether lignocellulosic particles of different

E. Roffael (\)

University of Göttingen, Göttingen, Germany

e-mail: eroffae1@gwdg.de

C. Behn

Büsgen-Institute, Department of Molecular Wood Biotechnology and Technical Mycology, University of Göttingen, Göttingen, Germany

B. Dix

Fraunhofer Institute for Wood Research, Wilhelm-Klauditz-Institut (WKI), Braunschweig, Germany dimensions have the same formaldehyde emission potential. The question is justified by the fact that, e.g., particles of different particle size have in general different surface areas and may also be widely different in the extractive content (Lelis 1995). Schäfer and Roffael (2000) delivered ample evidence that in softwoods (e.g. pine and spruce) extractives affect conspicuously the formaldehyde release and that removal of extractives from wood decreases the formaldehyde emanated from wood by hydrothermal treatments.

The aim of the work was to measure the formaldehyde release of particles from a mixture of softwoods (pine and spruce) used industrially for making particleboards.

\section{Materials and methods}

The formaldehyde release from the particles with different sizes, obtained by fractionation of the wood furnish through sieves of different mesh size, was measured using the flask method (EN 717-3) after a reaction period of 3 and $24 \mathrm{~h}$. Moreover, the content of hot water extractives of the particles was determined.

\section{Results and discussion}

In Fig. 1 the formaldehyde release of the particles is exhibited. The results reveal that with decreasing particle size the emanation of formaldehyde increases. The difference in the formaldehyde release becomes increasingly obvious on extending the reaction time from 3 to $24 \mathrm{~h}$.

Interestingly, the hot water extractive content of the particles increases also in the same direction as the 


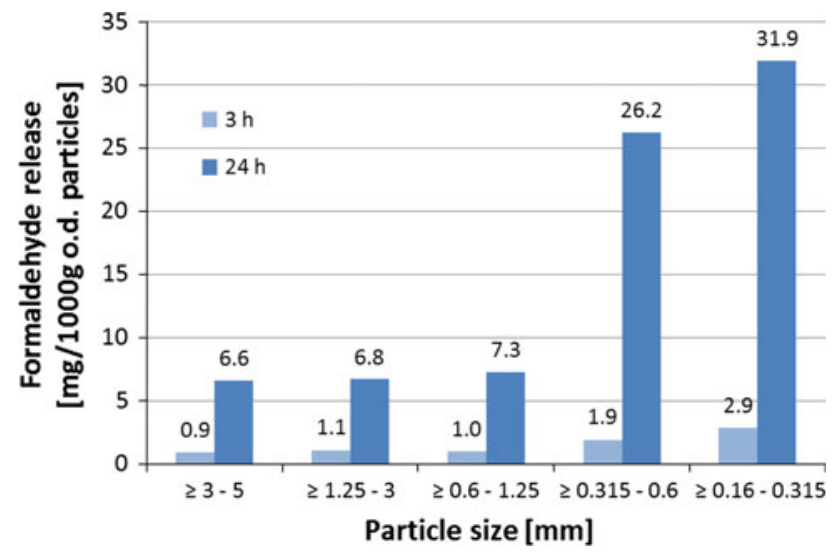

Fig. 1 Formaldehyde release from particles (pine wood) of different particle size, as measured after 3 and $24 \mathrm{~h}$ by the flask method (EN 717-3)

Abb. 1 Formaldehydabgabe von Holzspänen (Kiefernholz) in Abhängigkeit von der Spangröße, ermittelt nach 3 h und 24 h mit Hilfe der Flaschenmethode (EN 717-3)

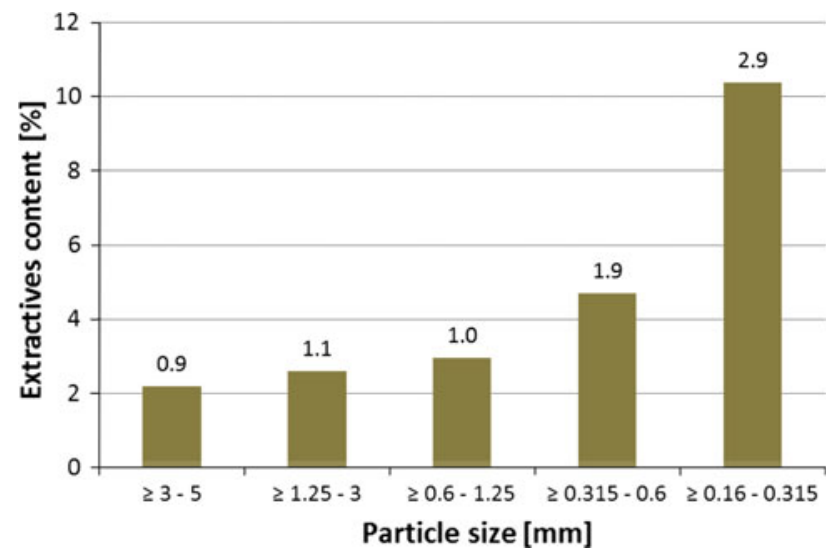

Fig. 2 Extractives content (hot water) of wood particles (pine wood) of different particle size

Abb. 2 Heißwasser-Extraktstoffgehalt von Holzspänen (Kiefernholz) in Abhängigkeit von der Spangröße formaldehyde release of the particles themselves (Fig. 2). This may be due to the increase in the surface area of the particles on decreasing the particle size. Also, water extractable extractives may contribute to this trend. It is well known that ray cells with a high content of lipophilic extractives are enriched in the fine fraction (Schäfer 1996).

Open Access This article is distributed under the terms of the Creative Commons Attribution License which permits any use, distribution, and reproduction in any medium, provided the original author(s) and the source are credited.

\section{References}

Boehme C (2000) Über die Formaldehydabgabe von Holz und ihre Veränderung während technischer Prozesse der Holzwerkstoffherstellung. Dissertation am forstwissenschaftlichen Fachbereich der Georg-August Universität Göttingen, Shaker Verlag ISBN 3-8265-8009-5

Hasch J, Grunwald D (2006) Formaldehydabgabe industriell hergestellter Holzpartikel. Holz-Zentralblatt 132:819

Lelis R (1995) Zur Bedeutung der Kerninhaltsstoffe obligatorisch verkernter Nadelbaumarten bei der Herstellung von feuchtebeständigen und biologisch resistenten Holzspanplatten, am Beispiel der Douglasie [Pseudotsuga menziesii (Mirb.) Franco]. Dissertation am forstwissenschaftlichen Fachbereich der Georg-August Universität Göttingen

Schäfer M (1996) Einfluß der Lagerung von Fichten- und KiefernIndustrierestholz aus der Profilzerspanung auf die Eigenschaften von Spanplatten und mitteldichten Faserplatten (MDF). Dissertation am forstwissenschaftlichen Fachbereich der Georg-August Universität Göttingen

Schäfer M, Roffael E (2000) Einfluß der Extraktstoffe von Fichtenund Kiefernspänen auf die Formaldehyd-Abgabe. Holz RohWerkst 58:258 